\title{
Pyrolysis Process of Fatty Acid Methyl Ester (FAME) Conversion into Biodiesel
}

\author{
Bambang Irawan', Rusdianasari², Abu Hasan ${ }^{3}$ \\ ${ }^{1}$ Applied Master of Renewable Energy Engineering, Politeknik Negeri Sriwijaya, Palembang, Indonesia \\ ${ }^{1}$ Oil Movement Production, PT. Pertamina (Persero) Refinery Unit III Plaju, Palembang, Indonesia \\ ${ }^{2,3}$ Chemical Engineering Department, Renewable Energy Study Program, \\ Politeknik Negeri Sriwijaya, Palembang, Indonesia
}

\begin{tabular}{|c|c|}
\hline Article Info & ABSTRACT \\
\hline Article history: & \multirow{9}{*}{$\begin{array}{l}\text { Biodiesel is a biomass fuel that can replace petroleum diesel fuel. One of the } \\
\text { advantages of biodiesel fuel as renewable energy source that it is more } \\
\text { environmentally friendly than fossil fuels because biodiesel significantly } \\
\text { reduces greenhouse gas emissions compared to fossil fuels. FAME (fatty acid } \\
\text { methyl ester) is a derivative product of CPO (crude palm oil) that has been } \\
\text { treated both physically and chemically. The main advantage of FAME lies in } \\
\text { the low content of impurities, especially sulphure and metal content. FAME } \\
\text { comes from vegetable oil raw materials, which contain high enough fatty } \\
\text { acids, around } 61-62 \% \text {, and nowadays, it is used as a mixture with petroleum } \\
\text { diesel. The characteristics of biodiesel obtained from the conversion of } \\
\text { FAME into biodiesel by pyrolysis at a temperature range of } 160-200{ }^{\circ} \mathrm{C} \\
\text { indicate that the biodiesel produced is density } 0.8475 \mathrm{~kg} / \mathrm{m}^{3} \text {, viscosity } 3.053 \\
\text { cSt, calculated cetane index (CCI) } 48.5 \text {, flash point } 59^{\circ} \mathrm{C} \text {, moisture content } \\
223 \text { ppm, and sulphure content of } 0.07 \% \mathrm{~m} / \mathrm{m} \text {. The results obtained are } \\
\text { below the maximum limit of the specified biodiesel quality requirements. }\end{array}$} \\
\hline Received July 11, 2021 & \\
\hline Revised August 10, 2021 & \\
\hline Accepted August 20, 2021 & \\
\hline Keywords: & \\
\hline FAME & \\
\hline Biodiesel & \\
\hline Pyrolysis & \\
\hline & \\
\hline
\end{tabular}

This is an open access article under the CC BY-SA license.

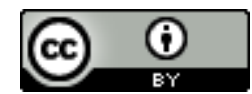

\section{Corresponding Author:}

Rusdianasari,

Chemical Engineering Department, Renewable Energy Study Program

Politeknik Negeri Sriwijaya,

Jalan Srijaya Negara, Bukit Besar, Palembang, Indonesia.

Email: rusdianasari@polsri.a.cid

\section{INTRODUCTION}

One of the most widely used energy sources in Indonesia comes from petroleum. The transportation sector is one of the most significant contributors to energy needs. Energy and Mineral Resources data in 2014 states that dependence on fossil energy, especially petroleum, in fulfilling consumption in Indonesia is still high at $96 \%$ (48\% oil, $18 \%$ gas, and $30 \%$ coal) of total consumption, and efforts to maximize the use of renewable energy has not been able to run as planned [1][2]. The high consumption of fossil energy is caused by people who tend to be wasteful in using energy. Meanwhile, on the other hand, Indonesia is facing a decline in fossil energy reserves that continues to occur and cannot be matched by the discovery of new energy reserves. In line with the increase in energy consumption, the supply of primary energy also increases.

One of the steps taken by the government is to make mandatory use of biofuels (BNN), especially biodiesel, to meet the increasing energy demands. The biodiesel mandate itself has been regulated in the Minister of Energy and Mineral Resources of the Republic of Indonesia No. 12/2015 concerning the third amendment to the regulation of the minister of energy and mineral resources number 32 of 2008 concerning the supply, utilization and trade system of biofuels as other fuels, then Minister of Energy and Mineral 
Resources of the Republic of Indonesia No. 41/2018 concerning the supply and utilization of materials biofuel type biodiesel in the framework of financing by the management agency of oil palm plantation funds. Decree of the Minister of Energy and Mineral Resources of the Republic of Indonesia No. 1936 K10/MEM/2018 regarding the procurement of biodiesel type biofuel to mix general types of fuel oil for the period September to December 2018 [3][4][5].

Biodiesel is a biomass fuel that can replace petroleum diesel fuel. One of the advantages of biodiesel fuel is that it is a renewable energy source that is more environmentally friendly than fossil fuels because biodiesel significantly reduces greenhouse gas emissions compared to fossil fuels. Biodiesel has the potential to solve energy problems in developing countries, especially countries that are not oil producers. In general, biodiesel has a cetane number range of 46-70, while petroleum diesel has a cetane number of 47-55 [6][7][8]. Emissions produced from biodiesel are cleaner, environmentally friendly and biodegradable. Biodiesel emissions are lower than petroleum-based diesel fuel. Emissions of particulates, soot and carbon monoxide are lower because biodiesel is an oxygen fuel.

Seeing these energy problems, the first step that must be taken is to look for renewable alternative energy that can support the community's energy needs, besides relying on fossil energy sources. According to Indoenergi, one source of biodiesel raw materials that is often used is Crude Palm Oil (CPO) and one of its derivative products such as Fatty Acid Methyl Ester (FAME) [9][10].

FAME, commonly known as biodiesel, is a fuel derived from vegetable oil raw materials containing high enough fatty acids, around $61-62 \%$, currently used as a mixture with petroleum diesel. FAME is a derivative product of CPO that has been treated both physically and chemically. The main advantage of FAME lies in the low content of impurities, especially sulphure and metal content. But on the other hand, FAME has organic compounds whose impacts need to be mitigated [11]-[15].

This study aims to produce biodiesel that does not have hygroscopic properties or does not contain high water content so that biodiesel will be obtained following the quality standards of the Director General of Oil and Gas and SNI. The biodiesel quality standard referenced in this study is the biodiesel quality standard from the Director General of Oil and Gas [16] [17].

\section{RESEARCH AND METHODS}

\subsection{Material and Equipment}

The FAME used as a sample is taken in the tank drainer (the part of the tank that serves to take samples or materials in the tank). The sample was deposited by allowing it to stand for 3 days. The conversion process takes place in a pyrolysis apparatus presented in Figure 1. Supporting equipment used for product analysis includes viscometer, density meter, flash point meter, X-ray sulphure, Karl Fisher Moisture Measurement and calculated cetane index (CCI).

\subsection{Sampling Method}

The pyrolysis process is carried out on a pyrolysis device designed with a volume of 7 liters. The cracking process at temperature variations of $161-170^{\circ} \mathrm{C}, 171-180^{\circ} \mathrm{C}, 181-190^{\circ} \mathrm{C}$ and $191-200^{\circ} \mathrm{C}$. Observed and recorded the volume of liquid fuel produced. The result of condensate is accommodated with a measuring cup to determine its volume and analyzed its properties.

\subsection{Sampling Testing}

The fuel product produced from the pyrolysis process with FAME as raw material is analyzed to determine biodiesel quality, including density, viscosity, cetane number, flash point, water content and sulphure content. Analysis of the characteristics of biodiesel fuel parameters was carried out to determine the quality of biodiesel after the product obtained from the pyrolysis process. The characteristics of the fuel obtained are compared with the biodiesel in PT Pertamina RU III whether there is a decrease in quality or remains the same, including in terms of water content. Data retrieval with temperature variations from $161^{\circ} \mathrm{C}$ to $200^{\circ} \mathrm{C}$ for 5 days. 


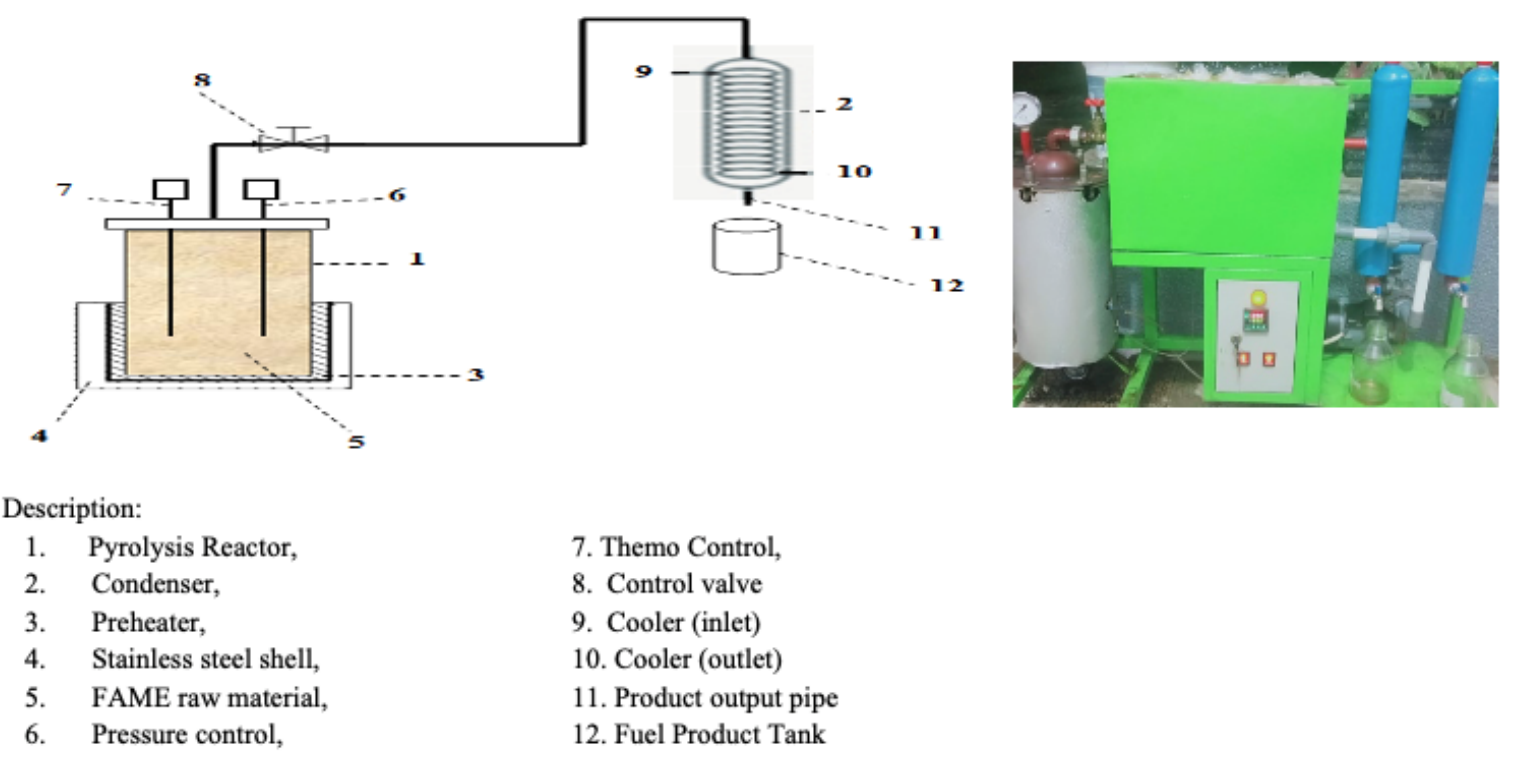

Figure 1. FAME Pyrolysis Reactor

\section{RESULTS AND DISCUSSION}

\subsection{Pyrolysis Process Results}

In this research, the pyrolysis process of Fatty Acid Methyl Ester (FAME) was carried out. The FAME used is 7 (seven) liters deposited or allowed to stand for at least 3 (three) days, then put into the pyrolysis heater. Heating started at room temperature of $30^{\circ} \mathrm{C}$, but at a temperature of $161^{\circ} \mathrm{C}$ to $200^{\circ} \mathrm{C}$ was taken as data due to the initial boiling point (IBP) obtained at $171^{\circ} \mathrm{C}$. The observed temperature ranges are $161-170^{\circ} \mathrm{C}, 171-180^{\circ} \mathrm{C}, 181-190^{\circ} \mathrm{C}$ and $191-200^{\circ} \mathrm{C}$ for 5 days from 02 to 06 February 2021.

According to the temperature range, all biodiesel results from the pyrolysis process are put into sample bottles and then analyzed for product quality, including density, cetane number or Calculated Cetane Index (CCI), viscosity sulphure content, flash point, residual carbon, and water content. Observations of pyrolysis results are in Table 1.

Table 1. Pyrolysis Result Volume Data

\begin{tabular}{llccccc}
\hline \multirow{2}{*}{ Research Data } & \multirow{2}{*}{ Date } & Unit & \multicolumn{5}{c}{ Pyrolysis Reactor Temperature $\left({ }^{\circ} \mathbf{C}\right)$} \\
\cline { 5 - 7 } & & & $\mathbf{1 6 1 - 1 7 0}$ & $\mathbf{1 7 1 - 1 8 0}$ & $\mathbf{1 8 1 - 1 9 0}$ & $\mathbf{1 9 1 - 2 0 0}$ \\
\hline & $02 \mathrm{Feb}$ & $\mathrm{ml}$ & 0 & 75 & 91 & 620 \\
& $03 \mathrm{Feb}$ & $\mathrm{ml}$ & 0 & 53 & 74 & 305 \\
& $04 \mathrm{Feb}$ & $\mathrm{ml}$ & 0 & 26 & 37 & 165 \\
$\begin{array}{l}\text { Pyrolysis on a basis of } \\
7 \text { liters of FAME }\end{array}$ & $05 \mathrm{Feb}$ & $\mathrm{ml}$ & 0 & 14 & 20 & 76 \\
& $06 \mathrm{Feb}$ & $\mathrm{ml}$ & 0 & 10 & 10 & 38 \\
$\begin{array}{l}\text { Total Volume of } \\
\text { Pyrolysis Oil }\end{array}$ & & $\mathrm{ml}$ & 0 & 178 & 232 & 1204 \\
\hline
\end{tabular}

Based on the observations of biodiesel fuel pyrolysis products, the volume differences produced from each temperature range, the temperature of $161-170{ }^{\circ} \mathrm{C}$ did not get the volume due to the initial boiling point (IBP) at $171{ }^{\circ} \mathrm{C}$, while at $191-200{ }^{\circ} \mathrm{C}$ the volume was high with a total volume of $1204 \mathrm{ml}$, can be seen in Figure 2. 


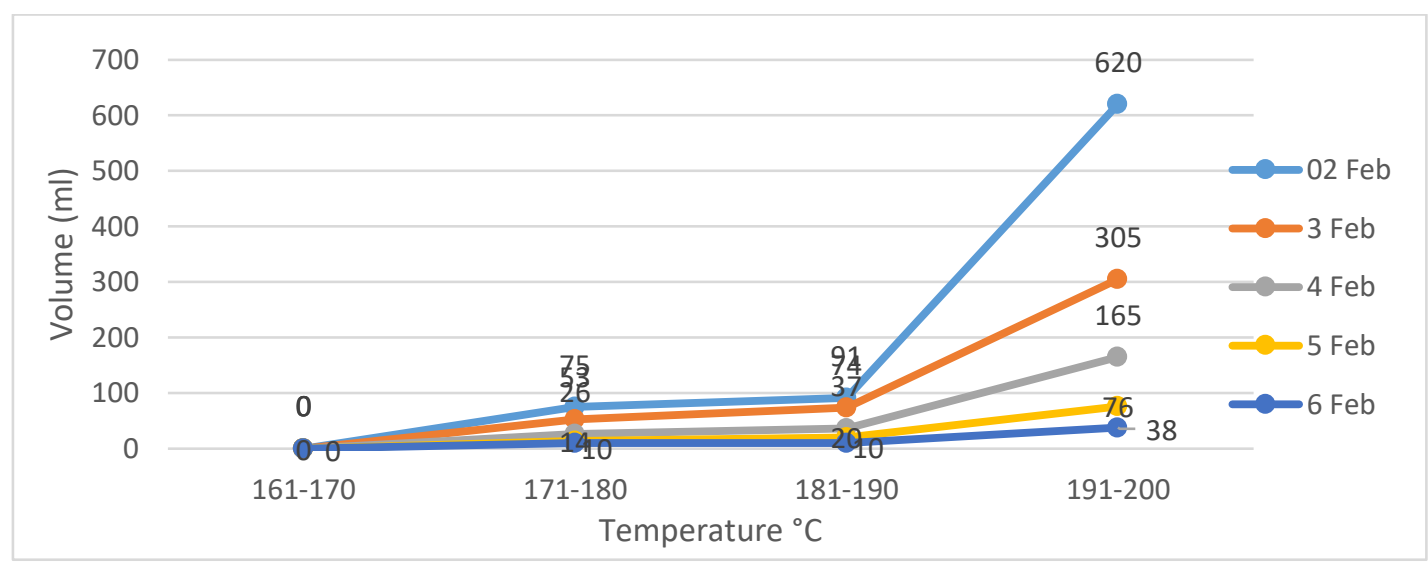

Figure 2. Biodiesel Volume Product of FAME

Based on observations of biodiesel products from the pyrolysis process, there are differences in color, namely the temperature range of $191-200^{\circ} \mathrm{C}$ (Figures $\mathrm{F}$ and $\mathrm{G}$ ) produces a darker color than the temperature range of $171-180{ }^{\circ} \mathrm{C}$ (Figure $\mathrm{B}$ and C) and $181-190{ }^{\circ} \mathrm{C}$ (Figure D and E), the physical appearance of the pyrolysis of FAME into biodiesel is shown in Figure 3.

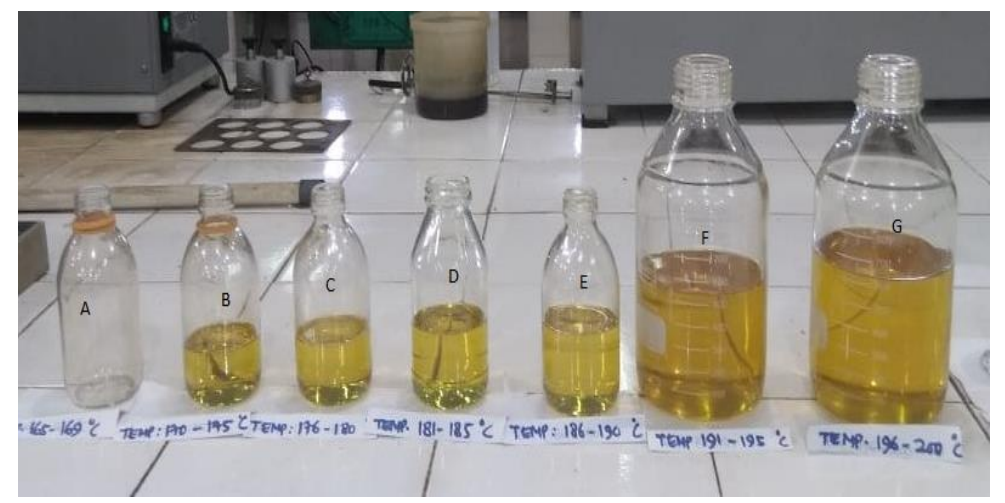

Figure 3. Biodiesel results from FAME at a temperature of $161-200{ }^{\circ} \mathrm{C}$

\subsection{Biodiesel Fuel Characteristic}

\subsubsection{Biodiesel Density}

Density is one of the parameters that determine the quality of biodiesel fuel. Density has a relationship with the carbon chain of the alkyl ester. The longer the carbon chain, the more biodiesel density will increase and reduce the degree of molecular saturation [18]. Density affects the calorific value and power produced by the combustion process of fuel. A high-density value indicates the number of components contained in the fuel. This component will prolong the atomization process of the fuel components during the combustion process so that it will increase the calorific value of the fuel combustion process [19]. According to the quality standard of the Director General of Oil and Gas, the required density for biodiesel is 815-860 $\mathrm{kg} / \mathrm{m}^{3}$ at $15{ }^{0} \mathrm{C}$. The density value following the required quality standards can produce a complete combustion reaction in the engine, while a density value that exceeds the standard will cause the combustion reaction to become imperfect so that it will increase emissions and wear on the engine [20]. The results of the analysis of the density value of biodiesel fuel can be seen in Figure 4.

Figure 4 shows that the composition of FAME raw materials starts at a temperature of $171-180^{\circ} \mathrm{C}$ with a density of $0.8390 \mathrm{~kg} / \mathrm{m} 3,181-190^{\circ} \mathrm{C}$ with a density of $0.8430 \mathrm{~kg} / \mathrm{m} 3$ and $191-200^{\circ} \mathrm{C}$ with a density of $0.8450 \mathrm{~kg} / \mathrm{m}^{3}$. All of them obtained density analysis results between the minimum and maximum limits of the required quality standards. When viewed from the temperature range, the density value of the biodiesel product is heavier if the biodiesel product is obtained at a higher temperature. 


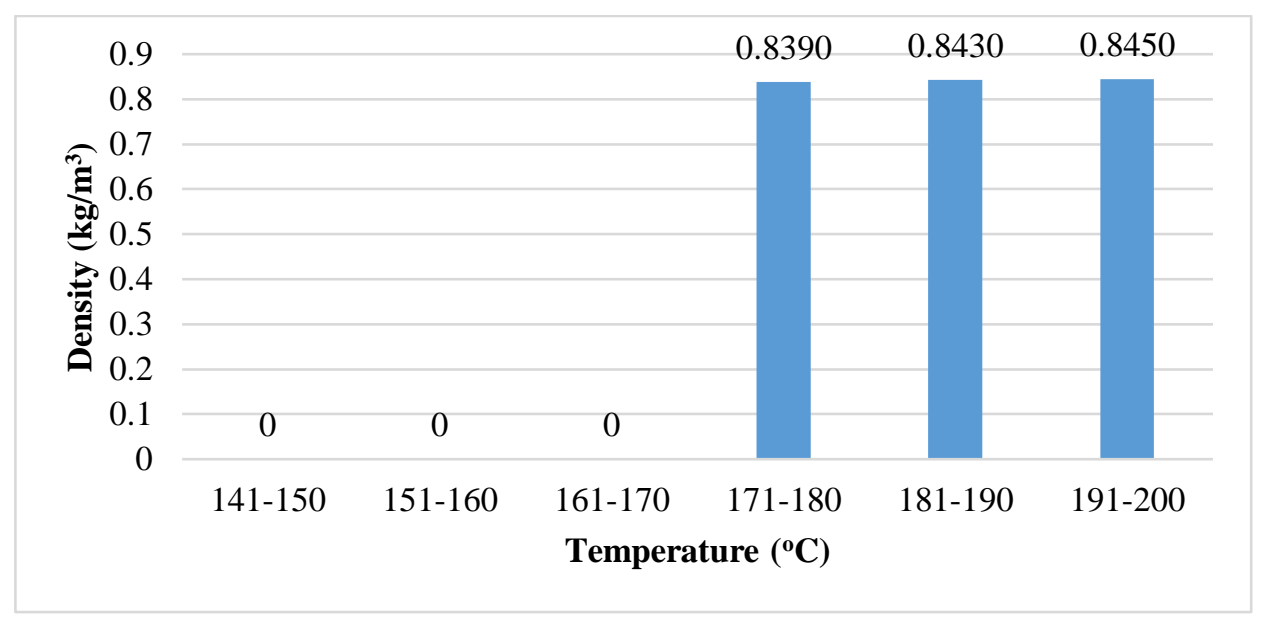

Figure 4. Biodiesel Density Results of FAME Pyrolysis

\subsubsection{Biodiesel Viscosity}

The viscosity that is too high will increase the friction loss in the pipe, make the pump work harder, and complicate the filtering process, thereby increasing the possibility of dirt being deposited and the fuel fogging process [19]. The viscosity that is too low will make the lubrication thin so that it can cause wear and damage to the combustion engine. FAME's kinematic viscosity is almost 2 times that of diesel oil, which is very important for engine lubricity, a vegetable-derived material that is relatively low in sulphure and aromatics content. In addition, the level of emission produced is also lower in terms of Particulate Matter (PM). According to the Director General of Oil and Gas, the required biodiesel viscosity value is $2.0-4.5 \mathrm{cSt}$ at $40{ }^{\circ} \mathrm{C}$. Based on the analysis of the viscosity value of biodiesel fuel, it can be seen in Figure 5.

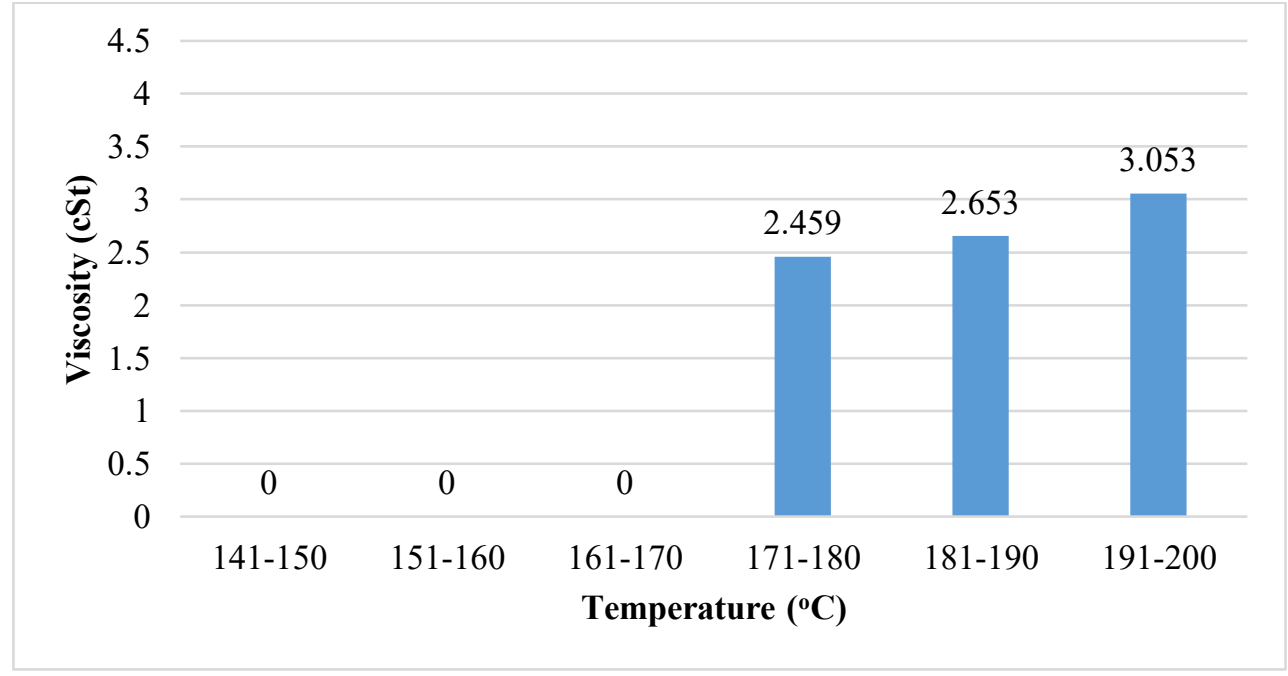

Figure 5. Viscosity of Biodiesel Pyrolysis Results FAME

Figure 5 shows that for FAME raw materials starting from a temperature of $171-180^{\circ} \mathrm{C}$ with a viscosity of $2.459 \mathrm{cSt}, 181-190^{\circ} \mathrm{C}$ viscosity $2.653 \mathrm{cSt}$ and $191-200^{\circ} \mathrm{C}$ viscosity $3.053 \mathrm{cSt}$. The results of the viscosity analysis are between the minimum and maximum required quality standards. When viewed from the temperature range, the viscosity value of biodiesel products is more significant if the biodiesel yields are obtained at higher temperatures.

\subsubsection{Biodiesel Calculated Cetane Index (CCI) Value}

A cetane number is a number that shows the results of testing the combustion quality of diesel fuel by comparing the reference fuel with the known cetane number in advance. The FAME cetane number according to SNI is at least 51, while the standard for petroleum diesel according to the Director General of Oil and Gas is at least 48 and the Calculated Cetane Index (CCI) is at least 45 . The cetane number shows how fast diesel engine fuel can be injected into the combustion chamber to burn spontaneously in the combustion 
chamber. The structure of the constituent hydrocarbons influences the cetane number of petroleum diesel. The lower the cetane number, the lower the ignition quality because it requires a higher ignition temperature [19]. The higher the cetane number, the faster the fuel burns, the better the thermodynamic efficiency. A high cetane number significantly affects the short time required between fuel injected and initiation, causing a good start and smooth engine sound [19]. A higher cetane number will ensure a good start and minimize the formation of white smoke.

In general, biodiesel has a cetane number range of 46-70, while petroleum diesel has a cetane number of 47-55 [19]. Emissions produced from biodiesel are cleaner, environmentally friendly and biodegradable. Biodiesel emissions are lower than petroleum-based diesel fuel. Emissions of particulates, soot, and carbon monoxide are lower because biodiesel is an oxygen fuel [20]. In testing diesel engines with vegetable oil fuels, it was found that vegetable oils have greater efficiency and engine power than diesel oil because the temperature of the exhaust gas produced is lower, but there is a decrease in the quality of the calorific value by an average of $2 \%$. With an average calorific value of $2 \%$ lower, but vegetable oil has a much higher cetane number, a shorter ignition delay will be obtained when compared to diesel oil. A shorter ignition delay of large and effective power will result in optimum performance [21].

The cetane number or calculate cetane index (CCI) of FAME is higher than petroleum diesel, so it is very good for improving auto-ignition performance in diesel engines. The longer the carbon chain of the fatty acid and the more saturated the molecule, the higher the devil number will be [22]. The results of the CCI analysis of biodiesel fuel in all pyrolysis temperature ranges. The results of the CCI analysis of biodiesel fuel at various temperature ranges can be seen in Figure 6.

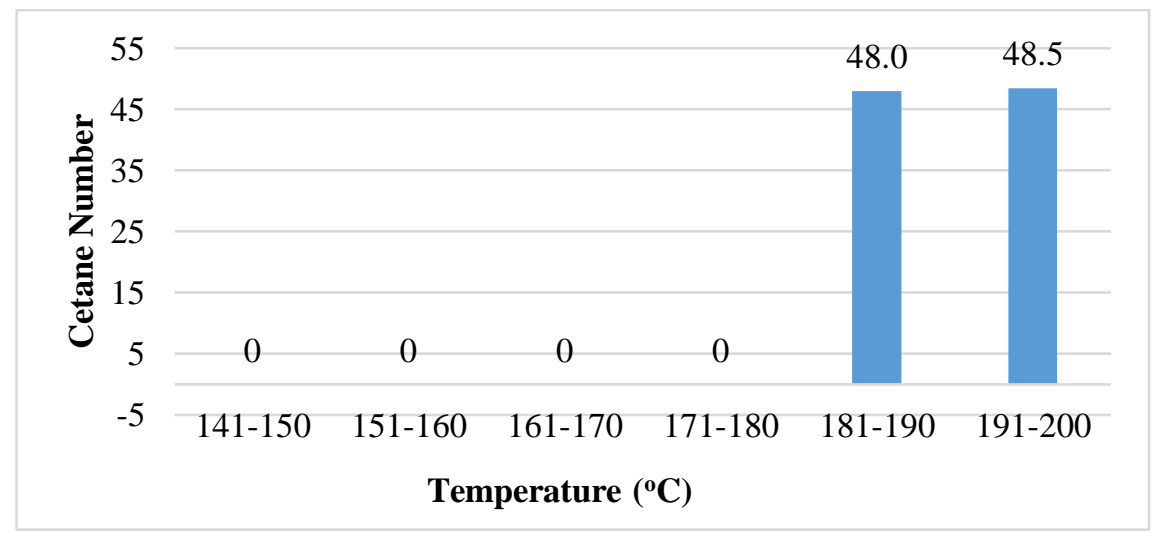

Figure 6. Pyrolysis Results Biodiesel Cetane Numbers

The ASTM D613-80 method is a measurement method in determining the quality of biodiesel combustion or determining the cetane number, starting from a temperature of $181-190^{\circ} \mathrm{C}$ with a cetane number of 48.0 , and $191-200^{\circ} \mathrm{C}$ with a cetane number of 48.5 . The temperature range obtained by the CCI analysis value is above the minimum quality limit required by the Director General of Oil and Gas.

\subsubsection{Biodiesel Flash Point}

The flash point is the lowest corrected temperature of a pressure of $760 \mathrm{mmHg}$ in oil vapor which ignites instantly when subjected to a test flame. Flash point is an important parameter related to the treatment process and storage of fuel. The high flash point ensures safer treatment and storage [23]. The presence of methanol in biodiesel products lowers the flash point of biodiesel so that biodiesel is flammable. Products that have a low viscosity value have a low flash point [24]. These properties happened because fluids with high viscosity are more difficult to ignite. The flash point value of FAME is much higher than the flash point value of petroleum diesel, so the blending formulation with more FAME composition will result in the flash point of the biodiesel produced also increasing. In the quality requirements of the Director General of Oil and Gas, the flash point value is set at a minimum value of $52{ }^{\circ} \mathrm{C}$ for petroleum-based diesel fuel. The flash point value of biodiesel that has been obtained from this research can be seen in Figure 7. 


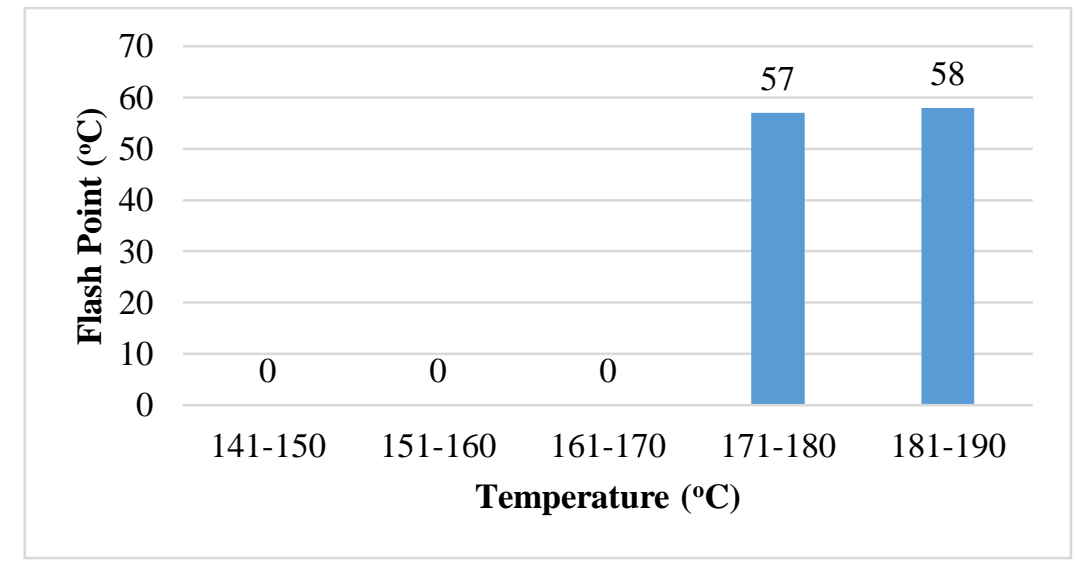

Figure 7. Flash Point Biodiesel Pyrolysis Results FAME

Figure 7 shows that FAME starts at a temperature of $171-180^{\circ} \mathrm{C}$ with a flash point of $57^{\circ} \mathrm{C}, 181$ $190^{\circ} \mathrm{C}$ flash point $58^{\circ} \mathrm{C}$ and $191-200^{\circ} \mathrm{C}$ flash point $59^{\circ} \mathrm{C}$. All of them obtained the results of flash point analysis above the minimum required quality standard. When viewed from the temperature range, the flash point value of biodiesel products is higher if the biodiesel yields are obtained at higher temperatures.

\subsubsection{Biodiesel Water Content Value}

In some countries with winter season, the water content contained in diesel engine fuel can form crystals that can block the flow of fuel in the engine injectors. In addition, the presence of water can cause corrosion and the growth of micro-organisms which can also block the flow of fuel into the combustion chamber. Sediment can also cause clogging and engine damage [25]. The analysis of the water content of biodiesel from FAME pyrolysis at various temperature ranges can be seen in Figure 8.

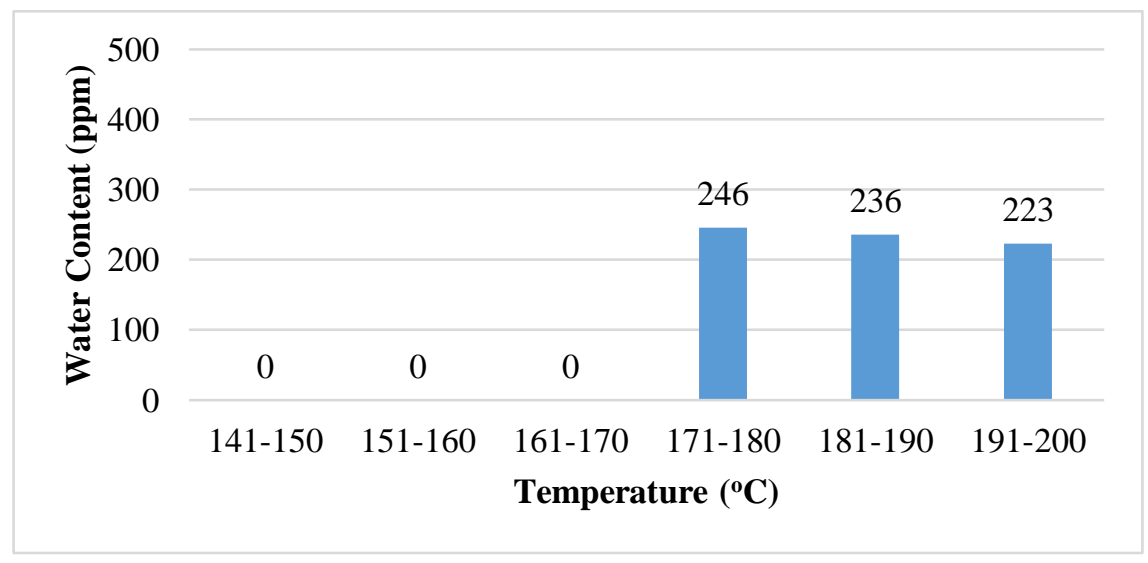

Figure 8. Biodiesel Water Content

Figure 8 shows that the composition of FAME raw materials starts from 171-1800C with the water content of $246 \mathrm{ppm}, 181-190^{\circ} \mathrm{C}$ water content of $236 \mathrm{ppm}$ and $191-200^{\circ} \mathrm{C}$ water content of $223 \mathrm{ppm}$. All of them obtained the results of water content analysis below the maximum required quality standard. When viewed from the temperature range, the value of the water content of biodiesel products is less if the biodiesel yields are obtained at higher temperatures.

\subsubsection{Biodiesel Sulphur Content}

Sulphur is the main problem for diesel engines, because the higher the sulphure content will provoke excess acid levels. This situation will result in damage to engine components, from scale to fuel lines. Scaling in the fuel lines can interfere with the supply of fuel that flows into the cylinders, the direct effect of disrupting engine performance, ranging from decreased power to more severe damage. This is where the term premature combustion or knocking occurs, which can cause the engine to tickle. High sulphure content can also damage the injector components and result in poor combustion. The lower the sulphure content, the 
cleaner exhaust gas emissions, fuel lines, diesel filters, and the combustion chamber. Sulphure also affects engine life. The higher the sulphure, which is acidic, the more the engine will rust easily. The effects of high sulphure levels in diesel fuel do not stop at vehicle damage. In the case of air pollution, combustion gases from the engine, when mixed with air, will form sulphure dioxide $\left(\mathrm{SO}_{2}\right)$. There will be an acidic composition that is harmful to the body when $\mathrm{SO}_{2}$ is mixed with water vapor

From the analysis of the pyrolysis results, it can be seen that biodiesel is an environmentally friendly diesel fuel because it produces better exhaust emissions, namely free sulphure. The sulphure value $<0.1$ $\% \mathrm{~m} / \mathrm{m}$ is far below the maximum value for the quality requirements of the Director General of Oil and Gas, which is $0.25 \% \mathrm{~m} / \mathrm{m}$ for 2017 . The test results show that the sulphure content of biodiesel is far below the maximum quality requirement. The results of the sulphure content analysis can be seen in Figure 9 .

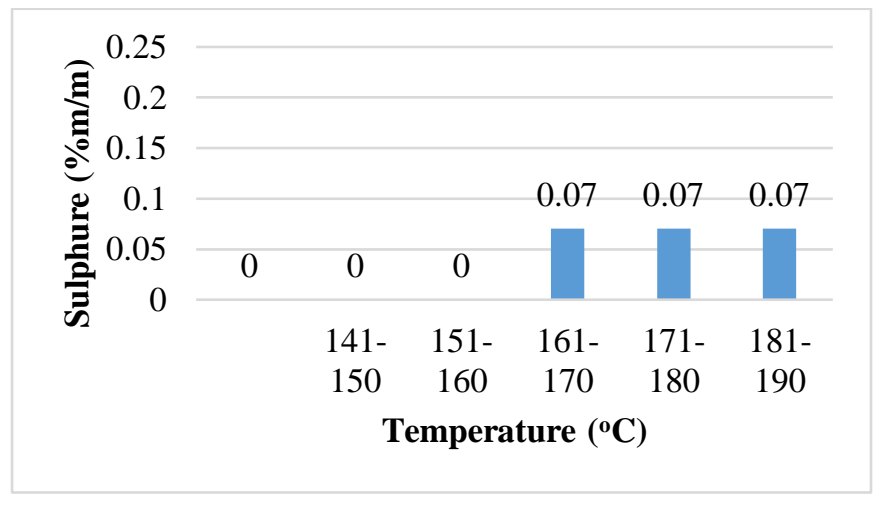

Figure 9. Sulphure Content of Biodiesel Pyrolysis Results of FAME

Figure 9 shows that the composition of FAME raw materials starts from a temperature of $171-200^{\circ} \mathrm{C}$ with a sulphure value of $0.07 \% \mathrm{~m} / \mathrm{m}$. All results obtained from the analysis that the sulphure content of biodiesel is far below the maximum required limit.

\section{CONCLUSION}

Biodiesel fuel developed as a diesel engine fuel derived from plant-based Fatty Acid Methyl Ester (FAME) has the same characteristics and even better than fossil fuel types of diesels. The results of the analysis on the pyrolysis system temperature range of $161-200{ }^{\circ} \mathrm{C}$ are included in the specification of the biodiesel quality standard of the Director General of Oil and Gas No. 28.K/10/DJM.T/2016 and SNI-047182-2015. Initial Boiling Point (IBP) from the pyrolysis system research to FAME $171^{\circ} \mathrm{C}$. The water content is one of the critical parameters, which is one of the measurement results of this pyrolysis, the result data obtained that the biodiesel water content is below the maximum limit of the specified quality requirements, namely the results of the analysis of the biodiesel water content of 219-246 ppm.

\section{ACKNOWLEDGEMENTS}

The author would like to thank the PT. Pertamina (Persero) RU III Plaju and Politeknik Negeri Sriwijaya for facilitating this research.

\section{REFERENCES}

[1] R Ploetz, R Rusdianasari, and E Eviliana. Renewable Energy: Advantages and Disadvantages Proceeding Forum in Research, Science, and Technology (FIRST), 2016

[2] Fitriana, Ira, Anindhita, Agus Sugiyono, Laode M.A. Wahid, Adiarso. Outlook Energi Indonesia. Inisiatif Pengembangan Teknologi Energi Bersih, Badan Pengkajian dan Penerapan Teknologi Pusat, Teknologi dan Sumber Daya Energi dan Industri Kimia, Jakarta. 2017.

[3] Juarsa, A. Syarif, L. Kalsum.Effect of Feed Composition and Product Quantity of Co-Processing Refined Blended Deodorized Palm Oil (RBDPO). Proceedings of the 4th Forum in Research, Science, and Technology (FIRST-T1T2-2020), 2020.

[4] RAN Moulita, Rusdianasari, and L. Kalsum, Converting Waste Cooking Oil into Biodiesel using Microwaves and High Voltage Technology, J. Phys: Conf.Ser. 1167 012033, 2019.

[5] S. Yunsari, Rusdianasari, and A. Husaini, CPO Based Biodiesel Production using Microwaves Assisted Method, J. Phys. Conf. Ser., vol. 1167, no. 1, 2019.

[6] Rusdianasari, A Syarif, M Yerizam, MS Yusi, L Kalsum, Y Bow. Effect of Catalyst on the Quality of Biodiesel from Waste Cooking oil by Induction Heating, Journal of Physics: Conf. Series 1500 (012052). 2020. 
[7] S Susumu, R Rusdianasari, S Yusi. Biodiesel Production from Waste Cooking Oil using Electrostatic Method, Indonesia Journal of Fundamental and Applied Chemistry (IJFAC) 3(3). 2020.

[8] Kurniawan A, Taqwa A, Bow Y. PLC Application as an Automatic Transfer Switch for on-grid PV System; Case Study Jakabaring Solar Power Plant Palembang J. Phys.: Conf. Ser. 1167 012026. 2019.

[9] Rusdianasari, Y Bow, RAN Moulita. Temperature Effect on the Biodiesel Quality from Waste Cooking Oil by Induction Heating, Journal of Physics: Conf. Series 1450 012003. 2020.

[10] Yusabri, M. Yerizam, A. Syarif. Characterization of Blending Composition Variations in Fatty Acid Methyl Ester (FAME) Biofuel with Diesel to Biodiesel. Proceedings of the 4th Forum in Research, Science, and Technology (FIRST-T1-T2-2020), 2020.

[11] Badan Standarisasi Nasional. 2015. Standar Nasional Indonesia Biodiesel 7182-2015. Jakarta. www.bsn.go.id.

[12] Utomo H, Sadnowo A and Ratna S S, Implementation of Automatic Transfer Switch Based on PLC at Electronic Engineering Laboratory, Department of Electrical Engineering, University of Lampung. Electrical Engineering and Technology vol 8. 2014.

[13] J. U. Putra, L. Kalsum, and Y. Bow. Effect of DC Voltage on Prototype of Biodiesel Electrostatic Separator with Glycerin from Waste Cooking Oil’, Indones. J. Fundam. Appl. Chem., Vol. 3(3). 2018.

[14] A. de R. Pinho et al., Fast pyrolysis oil from pinewood chips co-processing with vacuum gas oil in an FCC unit for second generation fuel production, Fuel, vol. 188, pp. 462-473, 2017.

[15] F. A. Twaiq, A. R. Mohamed, and S. Bhatia, Liquid hydrocarbon fuels from palm oil by catalytic cracking over aluminosilicate mesoporous catalysts with various Si/Al ratios, Microporous Mesoporous Mater., vol. 64, no. 1-3, pp. $95-107,2003$.

[16] A. Sugiyono, F. Anindhita, W. Abdul, I. Rahardjo, and R. E. Puspitasar, "BPPT Energi Indonesia 2018." p. 93, 2017.

[17] Andi Mulya A, Syaiful B and Zuchra H. Hydrodeoxygenation of Pyrolysis of Ketapang Wood (Terminalia catappa L) Becoming Bio-Oil Using Mo/Clay Catalyst, Jom Fteknik Vol 3 No 1, 2016.

[18] Hernando, J Leton P, Matia M P, Novella J L and Alvarez-Builla J. Biodiesel and FAME Synthesis Assisted Microwave: Homogenous Batch and Flow Processes. Fuel 86 p 1641-1644. 2007.

[19] A A Susilo 2010 Pre Design of Biodiesel Plant from CPO (Crude Palm Oil) and Methanol With Capacity of 500,000 Tons/Year (Surakarta: Jurusan Teknik Kimia Fakultas Teknik Universitas Muhammadiyah Surakarta)

[20] A Sugiyono, Anindhita, L M A Wahid and Adiarso, Outlook Energi Indonesia 2016 (Jakarta: Pusat Teknologi Sumber Daya Energi dan Industri Kimia dan Badan Pengkajian dan Penerapan Teknologi), 2016

[21] RAN Moulita, Rusdianasari, L. Kalsum, "Biodiesel Production from Waste Cooking Oil using Induction Heating Technology, Indonesian Journal of Fundamental and Applied Chemistry, Vol. 5 (1), pp. 13-17.

[22] S. Yunsari, A. Husaini, and rusdianasari, Effect of Variation of Catalyst Concentration in the Producing of Biodiesel from Crude Palm Oil using Induction Heater, Asian Journal of Applied Research and Community Development and Empowerment, Vo. 3(1), pp. 24-27., 2019

[23] Y. Bow, Rusdianasari, and S. Yunsari, CPO based Biodiesel Production using Induction Heating Assisted, Oil Palm Research and Review, Vol. 1(1), pp. 1-6, 2020.

[24] ES Yusmartini and Rusdianasari, Separation Process Biodiesel from Waste Cooking Oil using Ultrafiltration Membranes, Proceeding Forum in Research, Science, and Technology FIRST), 2016.

[25] E. Anzar, MS Yusi, and Y. Bow, Purification of Crude Glycerol from Biodiesel by-product by Adsorption using Bentonite, Indonesia Journal of Fundamental and Applied Chemistry (IJFAC) 3(3). Pp. 83-88, 2020.

\section{BIOGRAPHIES OF AUTHORS}

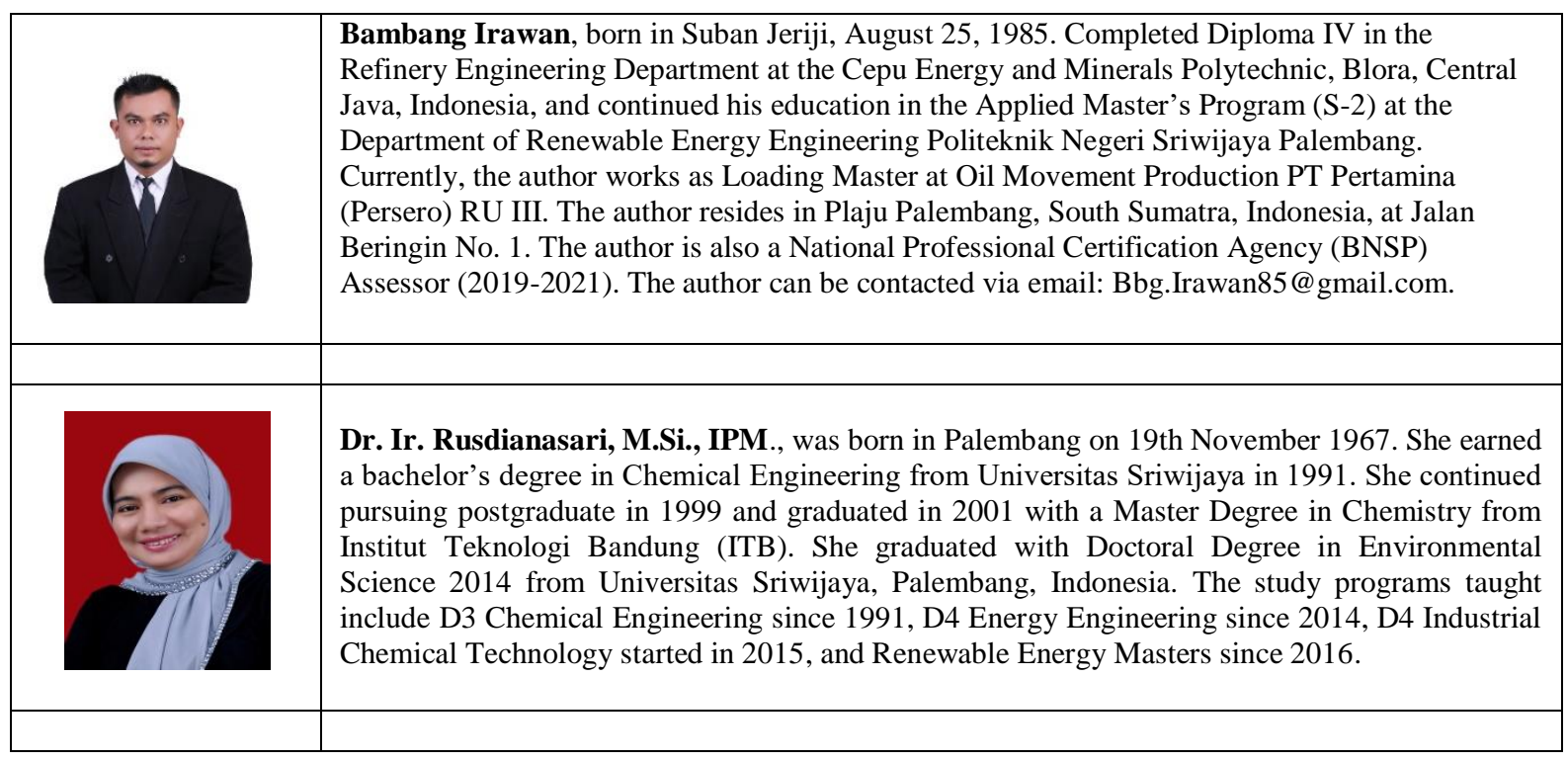




Dr. Ir. Abu Hasan, M.Si.
Abu Hasan, born in Palembang in 1964, completed his bachelor's degree in Chemical
Engineering at Sriwijaya University Palembang in 1991. In the same year, he was accepted to
work as a lecturer in Chemical Engineering at the Sriwijaya State Polytechnic Palembang until
now. Then he continued his master's study in Materials Science at the University of Indonesia
and completed it in 1996. In 2013 he completed his Doctoral studies at the Chemical
Engineering Study Program, Gadjah Mada University, Yogyakarta. The study programs taught
include D3 Chemical Engineering since 1991, D4 Energy Engineering since 2014, D4 Industrial
Chemical Technology started in 2016, and Renewable Energy Masters since 2017.

